
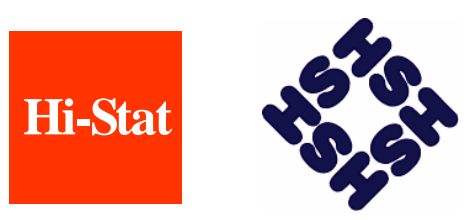

Discussion Paper Series

No.102

Reform of the Japanese Banking System

Masahiro Kawai

June 2005

Hitotsubashi University Research Unit for Statistical Analysis in Social Sciences A 21st-Century COE Program

Institute of Economic Research Hitotsubashi University Kunitachi, Tokyo, 186-8603 Japan http://hi-stat.ier.hit-u.ac.jp/ 


\title{
REFORM OF THE JAPANESE
}

\section{BANKING SYSTEM}

\author{
By \\ Masahiro Kawai \\ Institute of Social Science \\ University of Tokyo, Japan \\ 7-3-1 Hongo, Bunkyo-ku, Tokyo 113 JAPAN \\ kawai@iss.u-tokyo.ac.jp
}

\begin{abstract}
Japan has experienced a decade-long economic stagnation with a distressed banking sector in the 1990s. The absence of a credit culture to rigorously assess and price credit risks of borrowers, aggravated by weak prudential and supervisory frameworks, in the 1980s, the collapse of the asset price bubble in the early 1990s, and the lack of decisive, comprehensive strategy to address the banking sector problem at an early stage were largely responsible for the emergence of banking sector problems. All of these allowed a systemic banking crisis to emerge in 1997-98 and a large output loss during 1998-2002. The crisis ultimately prompted the government to take a more aggressive policy to tackle the problem. Sufficient progress has been made since then on banking sector stabilization, restructuring, and consolidation. The regulatory and supervisory framework has been strengthened in a way consistent with an increasingly market-oriented, globalized environment. As a result, the worst is over in the Japanese banking system, setting the stage for sustained economic recovery. Though bank capital may still be inadequate, safety nets are in place, the credit allocation has been made more rational. Remaining risks are limited to regional and smaller institutions that are vulnerable to weak, local economic conditions and hikes of the long-term interest rate.
\end{abstract}

Key words: Asset price bubble, Japan’s “lost decade,” systemic banking sector crisis, bank restructuring and consolidation, market-based regulatory and supervisory framework.

JEL classifications: E44, E51, G21, G28

Acknowledgement: This is a revised version of the paper presented to the conference, "International Economic Relations and Structural Change: Issues and Policy Options for Japan and the United States," organized by the University of Michigan and Hitotsubashi University and held in Ann Arbor on October 22-23, 2004. The author is thankful to Yasushi Harada, Akiyoshi Horiuchi, Takeo Hoshi, Takatoshi Ito, Hugh Patrick and Robert Stern for their useful comments and suggestions made on earlier versions. 


\title{
Reform of the Japanese Banking System
}

\author{
Masahiro Kawai
}

\section{INTRODUCTION}

The Japanese banking sector has been going through major restructuring, reorganization, and consolidation on a scale unprecedented in its history, all against a background of an increasingly market-oriented, more deregulated and globalized environment. This process was set in motion and precipitated by recent economic difficulties—asset price deflation and economic stagnation—-that started in the early 1990s and led to the systemic banking crisis of 1997-98.

This paper focuses on the state of the Japanese banking system that was exposed to an asset price bubble (in the late 1980s), its collapse (in the early 1990s) and the subsequent systemic crisis (in the late 1990s), and is undergoing recent reconstruction. These events raise several questions:

- What are the factors behind Japan's recent banking sector problem, particularly the 1997-98 systemic crisis?

- Why did the government fail to address the problem quickly and decisively?

- Has the financial authority adopted a comprehensive policy to resolve the banking sector problem since 1998?

- Has there been sufficient progress on banking (and corporate) sector restructuring and regulatory reform?

- What should be done to transform the Japanese banking system into a competitive, market-based system?

The paper is organized as follows. Section II reviews the macroeconomic develpments and banking sector conditions since the 1980s. Section III explores the 
causes of banking sector problems including factors that led to a systemic crisis in the latter half of the 1990s. Section IV examines the impact of banking sector distress on the regulatory framework, the state of macroeconomic conditions and monetary and fiscal policy frameworks. Section V evaluates the authority’s policy framework for bank restructuring and reform and the progress that has been achieved. It also discusses strategic responses of Japanese banks to their problems in the new market environment. Section VI concludes the paper.

\section{MACROECONOMIC DEVELOPMENTS AND THE BANKING SECTOR}

\section{Macroeconomic Performance and Policy}

The Japanese economy grew at 3.8 percent in the 1980s with low inflation, but slipped into a long period of stagnation in the 1990s. For example, the average annual growth rate of real GDP was 1.1 percent during 1992-2002. More recently, the economy experienced near-zero growth—at 0.1 percent in 1998-2002, though it finally started to show a sign of sustained recovery by recording eight consecutive quarters of positive growth, year over year, during 2002III-2004II. Noteworthy is the fact that nominal GDP has been contracting at an average 0.8 percent during 1998-03 because of persistent price deflation.

The rate of inflation in the 1980s was low-2.5 percent for the CPI and 2.3 percent for the GDP deflator-and it was even lower in the 1990 s - 0.3 percent for the CPI and -0.7 percent for the GDP deflator in 1992-2003. In the latter part of the sample, the price level fell fast, recording an average 0.6 percent decline in the CPI per year during 1999-2003 and an average 1.2 percent decline in the GDP deflator during 1995-2003. The pace of GDP deflator decline has been faster than that of the CPI decline, because the price of investment goods, an important component of the GDP deflator but not of the CPI, has been falling at a rapid pace in recent years. In more recent months, however, CPI deflation has moderated and is expected to end in 2005-06.

In addition, the rate of unemployment rose steadily from the beginning of the 1990s, 
reaching a peak of 5.4 percent in 2002. Though this peak unemployment rate was low relative to many OECD counterparts, it was a historical high for Japan.

Monetary policy stance has been alternating since the mid-1980s. With a rapidly appreciating yen exchange rate, the Bank of Japan adopted a loose monetary policy during 1986-88, which was an important factor behind the boom and sharp rises in asset prices. Due to economic overheating and asset price inflation, the Bank of Japan shifted to a tight monetary policy in the spring of 1989 and raised the official discount rate five times from 2.5 percent, prevailing in 1987-88, to 6.0 percent in 1991 . This monetary tightening was partly responsible for the collapse of the bubble in 1990-91. With the onset of asset price deflation, the Bank of Japan switched to easy money, which has been maintained until now—-the end of 2004.

Fiscal policy has also been expansionary during the post-bubble period. For example, fiscal spending rose from an average size of 32 percent of GDP in 1991 to 37 percent in 2003, with declining fiscal revenues_-from 34 percent to 28 percent of GDP during the same period. Every year, supplementary budgets were put in place to stimulate the economy. As a result the budget deficit has expanded and government debt has risen rapidly to an almost unsustainable level.

\section{Asset Prices}

There was an asset price bubble in the late 1980s. The pace of increase in asset prices—stock prices and land prices—was much faster than that of nominal GDP (Figure 1). The figure shows that, choosing 1980 as a reference year $(1980=100)$, the land price rose throughout the 1980s, reaching a peak level in September 1991 which was more than four times the 1980 level while nominal GDP then was only 1.8 times the 1980 level. The stock price also rose fast in the second half of the 1980s, reaching a peak in December 1989, which was close to six times the 1980 level. The magnitude of asset price inflation was indeed excessive in the 1980s in comparison to the movement of nominal GDP. 


\section{[Insert Figure 1]}

After peaking at the end of 1989, the stock price began to collapse in the following two years, losing more than half of its value by early 1992. While showing some recovery during 1993-96, the stock price again plunged in 1997-98. After peaking in 1991, the land price also started to decline soon thereafter, losing close to 20 percent of its value by 1992 and 60 percent by 1997. ${ }^{1}$ While the stock price exhibited some cyclical movements, both stock and land prices have declined as a trend throughout the 1990s and into the early 2000s. One can observe that the excessiveness of high asset prices has largely been eliminated relative to nominal GDP in the course of asset price deflation—by 1996 for the land price and by 2001 for the stock price—assuming the year 1980 was a meaningful reference base.

\section{Banking Sector Conditions}

The Japanese banks' stellar performance in the second half of the 1980s underwent a dramatic turnaround in the 1990s. During the second half of the 1980s, bank loans expanded against the expectation of robust growth, a stable price level, and an expansionary monetary policy. High loan growth was accompanied by high growth of deposits (Figure 2). Bank loans were concentrated in wholesale and retail trade, real estate, finance and insurance, and construction (Table 1), with real estate as collateral. Corporate borrowers in these sectors became highly indebted and exposed to risks of declines in the collateral value. The phenomenal expansion of bank loans contributed to the emergence of an asset price bubble, setting the stage for a subsequent banking crisis.

[Insert Figure 2]

[Insert Table 1]

\footnotetext{
${ }^{1}$ Measured by urban land price indexes in the six large city areas.
} 
The bursting of the bubble in the early 1990s reduced highly indebted firms' ability to repay their debt due to the decline in collateral value, thus creating non-performing loans (NPLs). Commercial banks' capital base began to erode as their real estate and equity holdings lost a substantial part of their values, prompting banks to call in loans to remain in conformity with the Basil capital adequacy guideline. ${ }^{2}$ Banks' credit squeeze was rather gradual with the rate of loan growth slowing over the first half of the $1990 \mathrm{~s},{ }^{3}$ only turning negative thereafter.

In the mid-1990s, numerous small financial institutions, such as housing loan companies (Jusen), credit cooperatives and regional banks became insolvent and were liquidated. ${ }^{4}$ Banking system distress became increasingly apparent during the course of $1997 .{ }^{5}$ Despite some restructuring efforts, Hokkaido Takushoku Bank, a major city bank, became unable to raise funds in the interbank market and had to announce the discontinuation of business operations in November, requesting a transfer of its healthy assets and liabilities in Hokkaido to Hokuyo Bank. Two large securities companies, Yamaichi and Sanyo, went bankrupt and two major banks, Nippon Credit Bank and the Long-Term Credit Bank of Japan, began to have management difficulties.

With a number of financial institutions experiencing difficulties or going bankrupt simultaneously, banks' share prices tumbled on the stock market in a full-blown systemic crisis. This crisis was systemic in that it was not limited to just a few banks. Several commercial banks were cut off from their access to the interbank market, some smaller banks were subjected to depositor runs, and the Japanese banking system as a whole faced an unusually high "Japan

\footnotetext{
${ }^{2}$ The Bank for International Settlements (BIS) announced in 1989, and implemented in 1992, the guideline on risk-weighted capital adequacy, which prompted the retrenchment of banks' lending operations globally.

${ }^{3}$ Commercial banks maintained, and even increased in some cases, their loan exposure to certain sectors, such as real estate and construction until the second half or the middle of the 1990s.

${ }^{4}$ These institutions included Tokyo Kyowa Credit Association, Anzen Credit Association, Cosmo Credit Cooperative, Kizu Credit Cooperative, Hyogo Bank and Taiheiyo Bank.

${ }^{5}$ See Nakaso (2001) for detailed accounts of the banking sector crisis and distress in the 1990s, particularly as viewed from the Bank of Japan's perspectives.
} 
premium” from late 1997 to most of $1998 .{ }^{6}$ In late 1998, Long-Term Credit Bank and Nippon

Credit Bank were placed under temporary nationalization. The government in a departure from its traditional “convoy” approach did not bail out these major long-term credit banks.

\section{CAUSES OF BANKING SECTOR PROBLEMS}

There are basically four causes for the banking sector crisis:

- Overextension of bank loans in risky areas under the general environment of inadequate supervision and regulation over banks during the bubble period;

- Severe negative impact of the bursting of the bubble and the subsequent asset price deflation, making bank loans non-performing;

- Economic slowdown in the 1990s; and

- A delay in policy action to decisively contain the banking sector problem.

\section{Overextension of Bank Loans with Inadequate Supervision and Regulation}

Several factors led to the overextension of bank loans in the second half of the 1980s.

First, financial liberalization in the 1980s allowed small financial institutions to venture into new areas, particularly funding housing finance companies (Jusen) and other real estate investments. ${ }^{7}$ This development, along with other deregulation, e.g. lifting of interest rate controls and of restrictions on non-bank lending, intensified competition among financial institutions and depressed interest rate spreads. In response, banks expanded into riskier lending, such as consumer loans, real estate loans, and small business lending, where the regulatory and supervisory framework proved to be inadequate.

\footnotetext{
${ }^{6}$ The capacity of banks to raise foreign currency funds, particularly in US dollars, diminished due to a decline in their creditworthiness - U.S. and European banks reduced credit limits applied to Japanese banks. Japanese banks were forced to raise funds at a large premium ("Japan premium") from U.S. and European counterparts in the interbank markets. From late 1997 into late 1998, the "Japan premium" rose significantly, coinciding with the severe problems in the Japanese financial market, peaking at 100 basis points in early December 1997 in the aftermath of the failures of Hokkaido Takushoku Bank and Yamaichi Securities. On the other hand, the banking crisis was not accmpanied by a massive flight of deposits out of the banking system as a whole, or a capital flight out of Japan. Hence the Japanese yen was never under downward pressure.

${ }^{7}$ Housing loan companies (Jusen) were established by banks and financial institutions to make residential mortgages. Initially they lent to home owners but their business turned towards financiang property development. These housing loan companies suffered from non-performing loan problems in the first half of the 1990s due to the collapse of property prices.
} 
Second, the deregulation of capital markets allowed large firms to increasingly shift away from banks to domestic and euro bond markets for funding (Hoshi and Patrick 2000). This shift induced major banks to increasingly channel their loans towards firms without sufficient access to domestic and international capital markets. As a result, the composition of bank clients changed from manufacturing to non-manufacturing firms and from low to high credit risk borrowers. Banks extended too many loans to firms in the real estate, construction, distribution, and finance sectors, which had been insulated from market competition, unlike those in the manufacturing sector, and hence had been less efficient, less productive and riskier.

Third, at the time of the asset price bubble, banks and borrower firms had unwarranted expectations of high economic growth, which allowed further expansion of collateral-based loans under the general conditions of low interest rates and inadequate prudential supervision by banks. Prudential supervision was inadequate—-leading to limited public disclosure of financial data, insufficient loan loss provisioning, and undercapitalization—and commercial banks had not developed a credit culture allowing the rigorous assessment and pricing of credit risk that is so necessary for sound banking. ${ }^{8}$ Collateral-based lending weakened banks' incentives to closely monitor borrower firms.

\section{Collapse of the Asset Price Bubble}

The late 1980s saw an expansion not only of bank loans but also of capital investment and labor employment. The bubble burst once the authorities sharply tightened their monetary policy—by raising the interest rate—and introduced credit ceilings on real estate-related bank

\footnotetext{
${ }^{8}$ Using contract-specific data on bank loans to Japanese firms, which originated between 1999 and 2001, Smith (2003) finds that Japanese banks charge substantially less spreads, on average, to Japanese borrowers than do foreign banks, after adjusting for many of the risk characteristics of the borrower. In addition, Japanese banks vary pricing less across these risks than do their foreing counterparts, indicating that Japanese banks tend not to discriminate bad risks from good. This problem was perhaps more serious in the 1980s.
} 
loans in 1990-91. ${ }^{9}$ The bursting of the bubble and the subsequent collapse of stock and land prices created the triple excesses of debt, capacity and labor—by transforming (a) much of the overextended loans into non-performing loans (NPLs) on the part of banks and (b) a large build-up of capital investment and employment into excess capacity and employment, respectively, on the part of firms.

All of these exerted a severe negative impact on the economy and the banking sector. Land price deflation, which continued throughout the 1990s and early 2000s, was particularly damaging because it substantially eroded the collateral value of bank loans.

The bursting of the bubble created substantial losses for firms that received loans from banks with real estate collateral because of sharp declines in the property price. As a result these highly indebted firms became unable to repay their loans, creating NPL problems for commercial banks. The asset price collapse also left problems with banks initially by wiping out hidden capital gains on their equity holdings, secondly by transforming certain corporate loans into non-performing loans. In response commercial banks became reluctant to extend loans to corporate borrowers and even began withdrawing existing loans from their borrowers. Banks did not attempt aggressively to resolve their NPLs at the early stage partly because they valued highly the maintenance of good bank-firm relationships and partly because the regulatory framework was not stringent, thus postponing the ultimate resolution of NPL problems.

Nonetheless, commercial banks began to dispose of NPLs in the early 1990s, initially at a gradual pace and later at a faster pace. With asset price deflation and weak economic activity, new NPLs continued to emerge throughout the 1990s and early 2000s. When price deflation began to embed itself in the economy in the second half of the 1990s, it became even harder to stop the emergence of new bank NPLs despite the banks' efforts to dispose of existing NPLs. ${ }^{10}$

\footnotetext{
${ }^{9}$ The causes and consequences of the asset price deflation in the 1990s are well documented. See for instance Hoshi and Kashyap (1999), Cargill, Hutchison and Ito (1997), and Kanaya and Woo (2000).

${ }^{10}$ For example, the amount of loans classified as "doubful" or below by major banks rose from 11.7 trillion yen in March 2001 to 15.4 trillion yen in March 2002 because of the emergence of new NPLs of 9.9 trillion yen, despite the disposal of 6.2 trillion yen.
} 


\section{Economic Slowdown}

With the collapse of investment and domestic demand, economic stagnation began in 1992. As highly indebted firms had not initiated restructuring efforts until the second half of the 1990s, they faced triple excesses in debt, capital and employment. As a result, labor productivity growth began to slow down. With an increasing number of bankruptcies among firms and financial institutions in the mid to the late 1990s, consumers began to lose confidence in the future because of the perceived collapse of life-time employment and the expectation of ever higher income. The economy appeared to have been trapped in a "bad" equilibrium. In addition, goods price deflation emerged in the mid-1990s, which gave a severe blow to the "growing-out" approach and aggravated banking sector difficulties.

There are two opposing views as to whether the economic slowdown in the 1990s caused banking sector problems or vice versa. We take the view that economic slowdown and banking sector problems mutually exacerbated the problems. If economic slowdown was one of the causes of banking sector problems, we need to explain the factors that led to the economic slowdown of the 1990s. There are basically three hypotheses to explain the slowdown—and even stagnation—in the 1990s, i.e., supply-side factors, demand-side factors and banking sector problems.

First, the importance of supply-side factors is pointed out by Hayashi and Prescott (2002) who argue that the problem was a sharp fall in total factor productivity (TFP) stemming from the lack of ability of the traditional Japanese economic model to adapt to the requirements of a more deregulated and competitive economic environment. Using a neoclassical growth model and calibration, they demonstrate that the stagnation of the Japanese economy during 1991-2000 could be explained by a fall in TFP growth. ${ }^{11}$ To the extent that such a sharp decline in TFP

\footnotetext{
${ }^{11}$ Average labor productivity growth declined from 3.75 percent in the 1980 s to 2.0 percent in the 1990 s. However, estimating TFP is not an easy task. Kawamoto (2005) finds little or no evidence of a decline in
} 
growth occurred, it is easy to understand that those firms that borrowed heavily from banks with the expectation of ever rising TFP during the bubble period must have faced difficulties in meeting payments once high TFP growth was not realized. Thus overextended loans of the bubble period turned into non-performing loans.

Second, the role played by demand-side factors is emphasized by Krugman (1998) who argues that an insufficiency of demand drove the economic downturn, as Japan fell into a liquidity trap-with the nominal interest rate unable to fall below zero and real interest rates too high to stimulate economic activity.

The third hypothesis is that banking sector problems were at least partially responsible for the economic stagnation of the 1990s. We return to this issue later.

\section{Policy Delay in Containing the Problem Early, Quickly and Decisively}

The financial authorities did not address the banking sector problem early and quickly enough and, thus, failed to adopt a comprehensive approach to resolve the banking sector problem until after the systemic crisis of 1997-98. In the absence of clearly a defined, well-functioning legal framework for dealing with insolvent institutions, there appeared to be some hesitation in taking decisive measures for fear that it might touch off a banking sector panic (Kanaya and Woo, 2000). Although the authorities introduced a broader range of measures to address aspects of banks’ problems more forcefully in 1996-97, the approach was not comprehensive. ${ }^{12}$ There are several reasons for the delay in decisive policy action:

- The initial approach was based on the expectation that a resumption of economic growth would restore financial health of banks and their clients.

- Keynesian fiscal policy supported minimum aggregate demand and helped insolvent corporations survive, particularly in the construction sector

- There was no domestic pressure-due to high savings, no inflation, relatively low unemployment, and no social unrest—nor external constraint—due to large foreign exchange reserves, large net external asset positions, no capital flight, no balance of

the pace of TFP growth in the 1990s. According to him, both cyclical utilization and reallocations of inputs played an important role in lowering measured prodcutivity growth.

${ }^{12}$ Cargill, Hutchison and Ito (2000) point out that the regulatory and supervisory framework was not stringent despite the emerging banking sector difficulties in the period leading up to the crisis of 1997-98. 
payments difficulties, and no currency crisis—-which otherwise would have prompted the government to accelerate the resolution of banking sector problems. ${ }^{13}$

The government did not appear to feel a sense of urgency for decisive action until it faced a systemic crisis in 1997-98. Essentially, the financial authorities avoided objectively recognizing the magnitude of NPLs and the state of bank balance sheets more generally. If decisive action had been taken and a comprehensive strategy put in place by the mid-1990s, the 1997-98 crisis might have been avoided, or at least its impact could have been mitigated.

\section{IMPACT OF BANKING SECTOR DISTRESS}

\section{Collapse of the Traditional "Convoy System"}

Under the government's protective policy, the banking sector had for a long time enjoyed exclusive access to the captive domestic financial markets characterized by the abundant savings and active investment of a large economy. The traditional banking-sector policy, called the “convoy system,” attempted to maintain a stable financial system capable of contributing to large-scale financial intermediation. The most important safety net in this framework was the implicit blanket protection of deposits through public confidence in the ability of the Ministry of Finance (MOF) and the Bank of Japan (BOJ) to prevent major financial instability. At least prior to 1991, the fundamental policy was to avoid bank failures. In the event of a bank failure, however, the official approach was largely ad hoc. Using its branch licensing and other authorities, the MOF encouraged stronger, healthier banks to absorb insolvent institutions—called the "hogacho" rescue operation—-through informal, administratively orchestrated, bank purchase and assumption (P\&A) transactions. For this purpose the MOF implicitly protected all deposits and allowed some regulatory forbearance, and the BOJ often provided liquidity assistance to prevent banking crises. This informal system functioned well in a growing economy with a stable political-bureaucratic environment.

\footnotetext{
${ }^{13}$ One of the distinctive features of Japan's banking crisis was the absence of a currency crisis. The twin crises-banking and currency crises-were an important feature of the East Asian financial crisis that affected Thailand, Indonesia, Malaysia and Korea.
} 
In the 1990s, however, it became increasingly difficult to pursue the "hogacho" style resolution—-to persuade healthier banks to participate in bail-out operations for other troubled banks—because even relatively strong banks began to experience a substantial deterioration in their balance sheets. Major shareholders and firms associated with Hokkaido Takushoku Bank, Yamaichi Securities and Sanyo Securities and other relatively strong banks refused to provide assistance. Temporary nationalization of Long-Term Credit Bank in October 1998 signified the end of the informal "convoy" system. Essentially, such a system became obsolete in coping with the market pressure that led to the 1997-98 systemic crisis.

One major factor behind the market pressure is the financial deregulation that had been underway since the 1980s, including interest rate liberalization, expansion of the scope of business for banks, non-banks’ entry into the lending business, opening of the domestic markets to foreign financial institutions, and the integration of domestic markets with global financial markets. For example, in late 1996, the government announced the "Financial Big Bang” reform, a blueprint to phase in free and open competition in a globalizing environment. ${ }^{14}$ Key aspects of these measures began to be introduced in late 1997. The sale of temporarily nationalized Long-Term Credit Bank to foreign interests, led by Ripplewood Holdings, indicated the government’s determination to open up major banking institutions to foreign ownership.

The end of the informal "convoy" system meant that financial authorities must establish a clearly defined regulatory and supervisory framework that is based on market

\footnotetext{
${ }^{14}$ The so-called "Financial Big Bang," adopted in 1996 was considered "a bigger bang” than the original big bang in London in 1986. The latter basically involved deregulation of fees for stock transactions and opening up of the London Stock Exchange to foreigners while the Tokyo "Financial Big Bang" brought down barriers between banking, securities, and insurance industries as well as liberalization of foreign exchange transactions. That is, barriers to non-bank and non-financial institutions as well as barriers to foreign participation were dismantled, potentially leading to greater competition and a more rapid reorganization of the financial industry than was experienced in the London big bang. The big bang was believed to encourage foreign banks to actively participate in the Tokyo markets, thereby taking advantage of opportunities in the world's second largest economy and abundant financial resources. The number of foreign banks in Japan steadily rose in the 1990s although the number declined slightly in the aftermath of
} 
principles to regulate and supervise banks and to resolve the problems ailing banks. This is necessary because the financial markets have become more competitive, integrated and global. A sequence of actions taken by the authority since 1998, including closure or temporary nationalization of nonviable banks, public recapitalization, use of prompt corrective action, stricter loan classification, greater loan loss provisioning, a move to a limited deposit insurance system, etc. is in line with this direction.

\section{Negative Impact on Real Economic Activity}

Although there is a view, with some empirical evidence, that the slowdown of economic activity was one of the factors that led to banking sector problems, there is also some evidence that banking sector problems played a role in causing economic stagnation. For example, the papers in Bayoumi and Collyns (2000) have highlighted the central role played by financial institutions in magnifying the impact of the decline in asset prices on the economy. Increases in bank loans, operating both directly and through a self-reinforcing cycle with increases in land and stock prices, helped explain the strong economic growth in the second half of the 1980s. The sharp fall of asset prices in the 1990s reversed this process as undercapitalized banks restrained lending to maintain capital adequacy standards. This reduced the effectiveness of macroeconomic policies as households and firms became unable to respond to monetary and fiscal stimulus because of the limited availability of funds from the banking system.

Dekle and Kletzer (2003) support the view that the banking sector problem can reduce economic growth on a sustained basis in a model of endogenous economic growth with commercial banks. When authorities protect bank deposits (explicitly or implicitly) and allow regulatory forebearance so that banks can accumulate NPLs without offsetting loan loss

its financial crisis. The expansion of their presence is most pronounced in the areas of corporate pension, 
provisions, the cost of disposing of NPLs must eventually be born by taxpayers. Higher taxes necessary for financial sector rehabilitation depresses economic growth. They find that the dynamics predicted by their model are largely consistent with the recent behavior of economic aggregates, asset prices and the banking system for Japan.

Brewer, Genay, Hunter and Kaufman (2003) provide additional evidence supporting the view that the financial sector problem exerts a negative impact on the economy. They find that announcements of three bank failures—Hokkaido Takushoku Bank in 1997 and Long-Term Credit Bank and Nippon Credit Bank in 1998—had negative impacts on equity prices of over 1,000 Japanese firms, both clients and non-clients of these failed banks. They find no significant difference in impacts between client and non-client firms. These findings suggest that bank failures represent "bad news" for all firms in the economy, not just for firms with relationships with the failed banks. Essentially the outbreak of the banking sector crisis did exert a negative impact on the overall economic activity, particularly by reducing business confidence throughout the economy, which may have aggravated the negative impact coming from lower TFP growth. A credit crunch also appears to have played a role. ${ }^{15}$

\section{Impact on Monetary Policy Transmission Mechanisms and Fiscal Conditions}

The banking sector difficulty has had serious implications for monetary policy and, through its negative impact on economic activity, fiscal conditions.

Since after the collapse of the asset price bubble in the early 1990s, a broad class of money supply, such as M2+CD, has not been growing fast despite the BOJ's seemingly easy monetary policy. The BOJ reduced the discount rate nine times between 1991 and 1995 and eventually adopted a zero interest rate policy (February 1999). Under the zero interest rate policy, the BOJ moved to "quantitative easing” (March 2001) in order to inject an adequate quantity of monetary

asset management, derivatives and other high-skill services.

${ }^{15}$ Hayashi and Prescott (2002) found no evidence of a "credit crunch"-possibly except for a brief period between late 1997 and early 1998-because both large and small firms were able to find financing for profitable investment opportunties. Motonishi and Yoshikawa (1999) find some evidence for a credit crunch for 1997 and 1998. See also Callen and Muhleisen (2003) and Dell’Aricia (2003). 
base into the banking system — by targeting the current account balances of commercial banks at the BOJ. Despite the traditional and non-traditional easy monetary policy, M2+CD has not been growing fast, reflecting the persistent contraction of commercial bank loans. Commercial banks saddled with large NPLs have become risk-averse and have stopped expanding new loans—or even have withdrawn loans from corporate borrowers. Instead, they have increased the holdings of long-term government bonds (JGBs) as "safe assets.” At the same time, indebted firms have had no appetite to borrow, particularly in a stagnant economic environment, and instead have been repaying their bank loans to reduce debt. ${ }^{16}$

Essentially, commercial banks have not performed as financial intermediaries. This suggests that, unless the banking sector eliminates the balance sheet problem and restores its financial health, it is difficult to reestablish its normal role as a financial intermediary. Resolution of banking sector problems is a condition for the restoration of a normal monetary policy transmission mechanism and, hence, for the greater effectiveness of monetary policy.

The banking sector problem is a reflection of the weakness of the corporate sector on the one hand, and can be a source of further economic stagnation and goods price deflation on the other. The causality goes both ways. The problem is that in an environment of economic stagnation and price deflation, it is difficult to reduce fiscal spending and contain budget deficits. In fact, since the early 1990s, the government expenditure has been rising because of the need to support aggregate demand, and the government revenue has been shrinking fast partly because of declines in income. As a result, large budget deficits have emerged throughout the 1990s and into the 2000s and the public sector gross debt/GDP ratio has steadily risen, to a level of 166 percent in 2003.

Expansion of government debt was tolerated for sometime because of low interest rate on JGBs. As the concern about fiscal sustainability mounts, however, upward pressure on long-term interest rates is unavoidable, which in turn would exacerbate fiscal conditions and the

\footnotetext{
${ }^{16}$ Indeed, the corporate sector has been a net saver since 1992.
} 
debt situation. ${ }^{17}$ To stop this, nominal GDP must grow at a rate higher than the long-term interest rate and/or a large primary surplus must be created over a substantial period of time. An eventual increase in the interest rate can expose commercial banks_-particularly regional banks holding JGBs - to another type of risk, i.e., capital losses not offset by equity price increases.

\section{POLICY FRAMEWORK FOR BANKING SECTOR RESTRUCTURING}

Next I consider the government's efforts to resolve, and recover from, the banking sector crisis and to reconstruct an efficient banking system through establishing an effective regulatory and supervisory framework. ${ }^{18}$ The government's approach to dealing with the bank distress problem was in transition during 1996-98. The previous policy had been based on protection and regulatory forbearance intended to support ailing banks, while allowing time for a recovery of economic growth and asset prices. However, stagnant economic performance and falling asset prices eventually intensified market pressure, leading to the 1997-98 crisis, which induced fundamental policy change.

\section{Stabilization of the Banking System}

Though the banking sector encountered a systemic crisis from late 1997 to 1998, it has been stabilized through more decisive actions than those in the earlier years.

Previously, deposits had been protected fully on an informal basis—despite the presence of explicit, limited deposit protection—, emergency liquidity assistance had been extended to troubled banks, and financial resources had been provided to encourage healthy institutions to merge troubled institutions. But the government had lost its willingness to use public funds to resolve banks' balance sheet problem since the 1995-96 Jusen episode when it reluctantly agreed to inject 680 billion yen to bail out specialized housing loan companies. This move was the first time that public funds were used directly to deal with financial instability in Japan. This was

\footnotetext{
${ }^{17}$ The sovereign rating of the JGB was downgrade by global rating agencies, which can heighten investor nervousness and concern about fiscal sustainability. Expanding debt will eventually exert upward pressure on the long-term interest rate.

${ }^{18}$ For guidance on this issue, see IMF (2003), which summarizes international lessons to be learned from banking crises in many other countries.
} 
extremely unpopular politically and the authorities were not prepared to repeat it. Nonetheless, they made efforts to contain the emerging difficulties in the banking sector. For example, in June 1996, the deposit insurance system was strengthened through a major amendment of the Deposit Insurance Law including: temporary suspension of limited deposit protection until March $2001^{19}$; and an increase in the insurance premium from 0.012 percent to 0.084 percent. At the same time, prompt corrective action was mandated as the new rule-based framework legislated required corrective actions when capital adequacy ratios deteriorated. ${ }^{20}$ These efforts were still intended to address problems for credit cooperatives rather than major banks. Injection of public funds into major banks was considered beyond the capacity of the Deposit Insurance Corporation (DIC).

The full-blown systemic crisis in 1997-98, however, prompted the authorities to take more decisive actions to stabilize the system. First, it was announced in December 1997 that up to 30 trillion yen of public money would be made available to the DIC by March 1998-comprised of 13 trillion yen to bolster bank balance sheets and 17 trillion yen to strengthen the DIC system. The Financial Supervisory Agency and the Financial Reconstruction Commission (FRC) were established..$^{21}$ Public funds of 1.8 trillion yen in March 1998 and 7.5 trillion yen in March 1999 were injected to help major banks meet the capital adequacy requirement. Two major banks, Long-Term Credit Bank and Nippon Credit Bank, were temporarily nationalized in October and December 1998, respectively. Public funds were augmented to a total of 60 trillion yen-more than 12

\footnotetext{
${ }^{19}$ This follows the MOF's announcement in June 1995 that the Deposit Insurance Corporation would protect all deposits of troubled banks at least for five years.

${ }^{20}$ If a commercial bank's capital ratio falls short of certain standards, the authorities shall request the bank to submit a management improvement plan to take specific action to remedy its situation. The bank will be required to classify its loans into five risk categories, subject to external audits.

${ }^{21}$ The Financial Supervisory Agency was created in June 1998, taking over the functions of supervision and inspection of the financial system from the MOF. The MOF retained the function of policy planning and created a new Financial System Planning Bureau by consolidating policy planning functions of the Banking and Securities Bureaus. In December 1998, the Financial Reconstruction Commission (FRC) was established as a parent body of the Financial Supervisory Agency, taking over oversight of the financial industry.
} 
percent of GDP—for financial support for banks in October $1998 .^{22}$ The prompt corrective action clauses were used starting in May 1999.

After public recapitalization, commercial banks began to adjust under the guidance of the newly created FRC and the Financial Supervisoy Agency. Bank restructuring took the form of closure of branches, private capitalization, stricter loan classification, greater provisioning and write-offs, and a cutback on cross-border operations. As a result of the measures taken, banks’ capital adequacy ratios improved and NPLs began to be seriously addressed. Banking sector stablity was largely restored. The "Japan premium” substantially narrowed in April 1999 when the market reacted favorably to the BOJ's downward guidance of the overnight inter-bank market rate to virtually zero percent.

\section{Banking Sector Restructuring: Public Recapitalization and NPL Disposal}

Public recapitalization. In March 1998, the government injected public resources to recapitalize 21 commercial banks, including all the city banks, for a total amount of 1.82 trillion yen, and in March 1999, an additional 7.5 trillion yen was put into 15 major banks, of which all city banks with the exception of the Bank of Tokyo Mitsubishi received 5.4 trillion yen (Table 2). Some banks increased capital by issuing preferred stocks and some issued subordinated debentures. Many banks were also encouraged to raise capital privately from the markets. Consequently, despite the negative impact on bank capital of sizable loan write-offs and loan loss provisions, the risk-based capital ratios of Japanese banks were raised by 1 to 2 percentage points by 1999 .

\footnotetext{
${ }^{22}$ Out of 60 trillion yen, 17 trillion yen was retained from the original plan to protect depositors of failed banks, while an additional 43 trillion yen—rather than the original 13 trillion yen—was made available in
} 
Table 2. Public Capital Injection into the Banking System, March 1998 and 1999

(Billions of yen)

\begin{tabular}{|c|c|c|c|c|c|c|c|}
\hline \multirow{3}{*}{$\begin{array}{l}\text { Banks } \\
\text { City Banks }\end{array}$} & \multicolumn{4}{|c|}{ March 1998} & \multicolumn{3}{|c|}{ March 1999} \\
\hline & Total & $\begin{array}{c}\text { Preferred } \\
\text { Shares } \\
\end{array}$ & $\begin{array}{l}\text { Subord. } \\
\text { Debt }^{(a)}\end{array}$ & \multirow[t]{2}{*}{$\begin{array}{l}\text { Subord. } \\
\text { Loans }\end{array}$} & Total & \multirow[t]{2}{*}{$\begin{array}{c}\text { Preferred } \\
\text { Stocks } \\
\end{array}$} & \multirow[t]{2}{*}{$\begin{array}{l}\text { Subord. } \\
\text { Debt }\end{array}$} \\
\hline & & & & & & & \\
\hline Tokyo Mitsubishi & 100 & 0 & 100 & 0 & -- & -- & -- \\
\hline Daiichi Kangyo & 99 & 99 & 0 & 0 & 900 & 700 & 200 \\
\hline Sakura & 100 & 0 & 100 & 0 & 800 & 800 & 0 \\
\hline Sumitomo & 100 & 0 & 100 & 0 & 501 & 501 & 0 \\
\hline Fuji & 100 & 0 & 100 & 0 & 1,000 & 800 & 200 \\
\hline Sanwa & 100 & 0 & 100 & 0 & 700 & 600 & 100 \\
\hline Tokai & 100 & 0 & 0 & 100 & 600 & 600 & 0 \\
\hline Daiwa & 100 & 0 & 0 & 100 & 408 & 408 & 0 \\
\hline Asahi & 100 & 0 & 0 & 100 & 500 & 400 & 100 \\
\hline \multicolumn{8}{|l|}{ Long-Term Credit Banks } \\
\hline Industrial Bank of Japan & 100 & 0 & 100 & 0 & 600 & 350 & 250 \\
\hline Long-Term Credit Bank ${ }^{(\mathrm{b})}$ & 176.6 & 130 & 0 & 46.6 & -- & -- & -- \\
\hline $\begin{array}{l}\text { Nippon Credit Bank }{ }^{(\mathrm{b})} \\
\text { Trust Banks }\end{array}$ & 60 & 60 & 0 & 0 & -- & -- & -- \\
\hline Mitsubishi Trust Bank & 50 & 0 & 50 & 0 & 300 & 200 & 100 \\
\hline Sumitomo Trust Bank & 100 & 0 & 100 & 0 & 200 & 100 & 100 \\
\hline Mitsui Trust Bank & 100 & 0 & 100 & 0 & 400.2 & 250.2 & 150 \\
\hline Yasuda Trust Bank & 150 & 0 & 150 & 0 & -- & -- & -- \\
\hline Toyo Trust Bank & 50 & 0 & 50 & 0 & 200 & 200 & 0 \\
\hline Chuo Trust Bank & 60 & 32 & 0 & 28 & 150 & 150 & 0 \\
\hline \multicolumn{8}{|l|}{ Regional Banks } \\
\hline Yokohama Bank & 20 & 0 & 0 & 20 & 200 & 100 & 100 \\
\hline Hokuriku Bank & 20 & 0 & 0 & 20 & -- & -- & -- \\
\hline Ashikaga Bank & 30 & 0 & 30 & & -- & -- & -- \\
\hline Total & $1,815.6$ & 321 & 1,080 & 414.6 & $7,459.2$ & $6,159.2$ & 1,300 \\
\hline
\end{tabular}

Note: (a) These debentures are generally of a consol nature and are therefore considered upper tier-2 capital. The only exceptions are those issued by Sanwa Bank and the Industrial Bank of Japan whose debentures are of fixed (10-year) duration and are therefore lower tier-2 capital, which is limited to no more than half of tier-1 capital.

(b) These banks were granted only part of the injection for which they applied.

Source: Deposit Insurance Corporation and the Financial Reconstruction Commission.

the October 1998 Supplementary Budget, consisting of 25 trillion yen for capital injections into weak but 
All city banks that received public funds for recapitalization were mandated by the Financial Function Early Strengthening Law to submit in March 1999 a restructuring plan for sound management, "Keiei no kenzenka no tameno keikaku." ${ }^{23}$ As a result, the official guidance by the Financial Supervisory Agency (later the Financial Services Agency) began to drive the banks' behavior and strategy. Main elements of commercial banks' restructuring plans are:

- Organizational restructuring, including mergers, subsidiaries, alliances with partners both in and outside the banking industry;

- Operational restructuring to improve ROEs, including cost-reduction for executive officers, personnel, operations and materials and retrenchment of overseas operations; and

- Resolution of NPLs.

In May 2003, Resona Holdings asked for public recapitalization when the capital adequacy ratios of Resona Bank and Resona Holdings for March 2003 fell short of the 4 percent threshold. The government injected 1.96 trillion yen based on the Deposit Insurance Law. In November, Resona Holdings made public a restructuring plan, including NPL disposal of 1.3 trillion yen-thereby reducing the NPL ratio from 9.3 percent in March 2003 to less than 4 percent by March 2005—and cutting employees and operational costs.

Recognition of NPLs. The authorities had long avoided recognizing the full extent of bank NPLs. However, the 1997-98 crisis led the authorities to assess the solvency and soundness of the capital bases of individual banks. The Ministry of Finance identified the total amount of NPLs for major banks as of March 1998 to be 22 trillion yen. The newly established The Financial Supervisory Agency, under the guidance of the Financial Reconstruction Commission (FRC) and together with the Bank of Japan, identified the total amount of NPLs for all deposit taking institutions to be 39 trillion yen as of March 1999. However, these inspections were based on self-assessment of NPLs by banks, and doubt arose as to whether these figures represented reality.

\footnotetext{
viable banks and 18 trillion yen for funding operations of temporarily nationalized banks.

${ }^{23}$ Of all the city banks, Tokyo-Mitsubishi alone did not receive public funds in 1999 and therefore did not submit such a plan.
} 
The Financial Services Agency (FSA), a new agency that replaced the Financial Supervisory Agency, launched a special inspection of bank loans for the period October 2001 to March 2002. The inspection was limited to large borrowers whose market indicators, such as share prices and credit ratings, had deteriorated rapidly, and where the exposure of each bank was high. This process resulted in inspections of loans to 149 companies, and a quarter of the “normal” or "need attention” loans examined were reclassified as bad loans_- "bankrupt” or "in danger of bankruptcy” loans. ${ }^{24}$ The increased regulatory pressure led to a dramatic change in loan classifications by the banks in 2002, with the value of NPLs rising by more than 25 percent from 33.6 trillion yen in March 2001 to 43.2 trillion yen in March 2002 (see Table 3). The FSA conducted the second round special inspection in 2003, covering 167 borrowers including 142 that were inspected in the first round in 2001, with total loans of 14.4 trillion yen from 11 major banks.

[Insert Table 3]

Disposal of NPLs. Commercial banks have been addressing NPL problems since the beginning of the 1990s and have accelerated the pace of disposal since 1999. Banks have disposed of close to 90 trillion yen—about 17 percent of 2002 GDP—in the last ten years. Despite such efforts, the pace of net reduction of bank NPLs has been slow due to the emergence of new NPLs.

\footnotetext{
${ }^{24}$ Bank loans are classified into five risk categories, i.e., normal, need attention, special attention, in danger of bankruptcy, and bankrupt/de facto bankrupt. "Normal loans" are loans to borrowers having strong results and no particular problems with its financial condition. "Need attention loans" are loans to borrowers having problems with lending conditions, fulfilment or its financial conditions, etc. "Special attention loans" are a subset of "need attention loans," which are overdue more than 3 months or having problems with lending conditions (i.e., waivers, reductions or deferrals of interest). "In danger of bankruptcy loans" are loans to borrwers facing business difficulties and failing to make adequate progress on its business improvement plan, so that there is a possiblity of falling into bankruptcy in the future. "Bankrupt loans" are loans to legally and formally bankrupt borrowers, including bankruptcy, liquidation, reorganization, rehabilitation, composition and suspension of dealings on the bill exchange, while "de facto bankrupt loans" are loans to borrowers who are in serious business difficulties and considered to be impossible to
} 
Nonetheless, the stock of NPLs declined in March 2003 for the first time in five years. NPLs in March 2004 were even lower than in March 1998.

In October 2002, the FSA announced the Program for Financial Revival (PFR), an ambitious three-pronged strategy to accelerate bank restructuring:

- Bank shareholding to be reduced to 100 percent of tier-1 capital by September 2006.

- Loan classification and loan loss provisioning to be strengthened through (a) new inspection of major banks' loan classification and provisioning, (b) introduction of the discounted cash flow method for provisioning loans to large "special attention" and "in danger of bankruptcy" borrowers, (c) harmonization of loan classification for large borrowers across banks, (d) disclosure of the gap between major banks' self-assessment of problem loans and FSA assessment, and (e) external audit of capital adequacy ratios, starting in FY2003. There are also measures to improve the classification of loans to small businesses.

- Banks are to remove 50 percent of new NPLs within one year and 80 percent within two years, with a target of reducing the proportion of major banks' NPLs by half by March 2005 from its level of 8.6 percent in March 2002. However, no target has been set for regional banks.

Following the PFR, the government has pursued the implementation of new policies in support of financial sector restructuring. The regulatory authority—Financial Services Agency (FSA) — changed its inspection manual to encourage large banks to use the discounted cash flow (DCF) method in provisioning on loans to large borrowers (greater than 10 billion yen). The tax authorities have recognized provisions against the worst categories of loans as a cost for tax purposes. The FSA requested major banks to enhance the disclosure of information on future taxable income in order to help reduce deferred tax assets (TDAs). Finally, the FSA conducted several types of special inspections to further bank restructuring.

\section{Banking Sector Consolidation}

Japanese banks are now restructuring and repositioning on the heels of their prolonged financial distress. The restructuring and repositioning are pursued against the background of the

rebuild, though not yet leagally and formally bankrupt. See the Appendix Table for details of loan classification. 
Financial Big Bang, the IT revolution, ${ }^{25}$ and a policy shift from protection to a more market-based framework. Moreover, the general overbanking situation has aggravated banking businesses due to the shrinking market size, economic stagnation and a structural change in financial intermediation towards direct finance and capital markets. ${ }^{26}$ Their strategic objectives have begun to emphasize the improvement of ROE.

Motivated by distress, large Japanese banks have engaged in a series of defensive mergers. These moves have resulted in the establishment of five banking groups, i.e., Mitsubishi Tokyo Financial Group (MTFG), Mizuho Financial Group (MHFG), UFJ Holdings, Sumitomo Mitsui Financial Group (SMFG), and Resona Holdings. The largest group is Mizuho Financial Group with a consolidated asset portfolio of 138 trillion yen as of March 2004, accounting for close to twenty percent of the total asset portfolio of all domestically licensed banks. Mitsubishi Tokyo Financial Group is the second largest, followed by Sumitomo Mitsui Financial Group and UFJ Holdings. Resona Holdings is the smallest (see Table 4). MTFG and UFJ Holdings are scheduled to merge in October 2005, forming the largest group in Japan.

\footnotetext{
${ }^{25}$ In the age of IT revolution, banks will have to compete fiercely to provide high-quality and customized financial services at low costs. The barriers between traditionally segmented sectors such as banking, security, insurance, and even commerce will diminish and all market participants will have to strive to provide comprehensive financial services with the result that financial markets will become larger, more integrated, and competitive. Furthermore, there will be a need for infrastructure services for electronic certification, identification, credit evaluation, payment settlement, and e-securities. Banks will, in partnership with IT-related corporations, develop and install the systems which will provide such infrastructure services.

${ }^{26}$ As a result of large corporations' increasing reliance on capital markets for funding, corporate demand for bank services is changing from loan business to new areas such as: investment banking; development and provision of services facilitating the liquidity of securities and project finance; and technical services in developing and installing a new accounting framework designed to conform to international standards. In addition, Several major banks have ceased foreign operations altogether. Other major banks that remain internationally active have also cut back on their presence overseas, shifting the operational focus towards core banking businesses with Japanese firms and their affiliates. The overall number of bank branches and human resources overseas began to decline in 1996 particularly in North America. In the midst of overall retrenchment, Asia is still considered the last best hope for Japanese banks, despite their relatively reduced presence in the region. See Kawai, Ozeki and Tokumaru (2002).
} 
Table 4: Banking Groups and Consolidated Assets

(Billions of yen)

\begin{tabular}{|c|c|c|c|}
\hline New Groups & $\begin{array}{c}\text { Major Subsidiary } \\
\text { Banks } \\
\end{array}$ & Former Banks & $\begin{array}{c}\text { Consolidated } \\
\text { Assets } \\
\end{array}$ \\
\hline $\begin{array}{l}\text { 1. Mizuho Financial Group } \\
\text { (MHFG) } \\
\text { (Established in January 2003) }\end{array}$ & $\begin{array}{l}\text { Mizuho Bank, Mizuho } \\
\text { Corporate Bank, } \\
\text { Mizuho Trust \& Bankig }\end{array}$ & $\begin{array}{l}\text { Industrial Bank of } \\
\text { Japan, Daiichi Kangyo, } \\
\text { Fuji, Yasuda Trust } \\
\text { Banks }\end{array}$ & $\begin{array}{r}137,750 \\
(1,541)\end{array}$ \\
\hline $\begin{array}{l}\text { 2. Mitsubishi Tokyo } \\
\text { Financial Group (MTFG) } \\
\text { (Established in April 2001) }\end{array}$ & $\begin{array}{l}\text { Bank of } \\
\text { Tokyo-Mitsubishi } \\
\text { (BTM), Mitsubishi } \\
\text { Trust \& Banking } \\
\text { Corporation }\end{array}$ & $\begin{array}{l}\text { Bank of } \\
\text { Tokyo-Mitsubishi } \\
\text { (BTM), Mitsubishi } \\
\text { Trust Bank, Nippon } \\
\text { Trust Bank }\end{array}$ & $\begin{array}{r}106,619 \\
(1,258)\end{array}$ \\
\hline $\begin{array}{l}\text { 3. Sumitomo Mitsui Financial } \\
\text { Group (SMFG) } \\
\text { (Established in December } \\
\text { 2002) }\end{array}$ & $\begin{array}{l}\text { Sumitomo Mitsui } \\
\text { Banking Corporation } \\
\text { (SMBC) }\end{array}$ & $\begin{array}{l}\text { Sumitomo Bank, } \\
\text { Sakura Bank }\end{array}$ & $\begin{array}{r}102,215 \\
(1,248)\end{array}$ \\
\hline $\begin{array}{l}\text { 4. UFJ Holdings } \\
\text { (Established in April 2001) }\end{array}$ & $\begin{array}{l}\text { UFJ Bank, UFJ Trust } \\
\text { Bank }\end{array}$ & $\begin{array}{l}\text { Sanwa Bank, Tokai } \\
\text { Bank, Toyo Trust \& } \\
\text { Banking }\end{array}$ & $\begin{array}{l}82,134 \\
(1,000)\end{array}$ \\
\hline $\begin{array}{l}\text { 5. Resona Holdings } \\
\text { (Established in December } \\
\text { 2001) }\end{array}$ & $\begin{array}{l}\text { Resona, Saitama } \\
\text { Resona, Kinki Osaka, } \\
\text { Nara Banks, Resona } \\
\text { Trust \& Banking }\end{array}$ & $\begin{array}{l}\text { Asahi Bank, Daiwa } \\
\text { Bank }\end{array}$ & $\begin{array}{l}39,841 \\
(1,288)\end{array}$ \\
\hline
\end{tabular}

Source: Individual groups' website. 
These groups' strategic objectives are:

- Gaining maximum market power in the respective areas of competency or a niche market;

- Attaining economies of scale and drastic reduction of operational costs;

- Generating sufficient profits to invest in IT development; and

- Building a critical mass capacity in strategic areas, e.g., investment banking, asset management, and high-skill, fee-based businesses.

All these objectives are being pursued to substantially improve ROEs that now lag behind those of competitive foreign banks.

While the consolidation of the banking sector will presumably result in economies of scale, it remains to be seen whether desired results will be secured. For instance, there is an expectation that the large size of banks will reduce operational costs per unit of asset, given the inverse relationship between the asset size and costs per unit of asset. However, reductions in operational costs and gains in efficiency will result in increases in asset size if and only if all the redundancies that are created by the merger are eliminated and the opportunities for synergy are fully exploited.

\section{Progress on Corporate Restructuring}

Corporate sector restructuring is the mirror image of bank NPL resolution. The latter requires the former. There are in general three frameworks for accelerating corporate restructuring:

- Legal insolvency procedures;

- Voluntary out-of-court negotiations for corporate restructuring — based on the London rules of INSOL; and

- Corporate restructuring by public asset management companies, such as the RCC and IRCJ

The Japanese insolvency system consists of two liquidation procedures_-Liquidation (Hasan) and Special Liquidation (Tokubetsu seisan)—and three reorganization procedures—Corporate Restructuring (Kaisha kosei), Civil Rehabilitation (Minji saisei) and 
Corporate Reorganization (Kaisha seiri). Because these insolvency procedures were legislated separately a long time ago, the system lacked coherence and was outdated. To help accelerate corporate restructuring, more flexible procedures have been introduced (see Table 5). As a result, the Japanese legal system is no longer regarded as an impediment to corporate restructuring.

Table 5. Legal and Instituional Changes to Facilitate Corporate Restructuring

\begin{tabular}{|c|c|c|}
\hline Year Changed & Laws, Procedures and Institutions & Contents \\
\hline 1997 & Commercial Codes & Procedures for corporate mergers rationalized. \\
\hline December 1997 & Anti-Monopoly Law & Establishment of pure holding companies allowed. \\
\hline March 1998 & Financial Holding Company Law & Establishment of financial holding companies allowed. \\
\hline 1999 & Commecial Codes & $\begin{array}{l}\text { Share swaps introduced; procedures related to parent and } \\
\text { subsidiary companies rationalized. }\end{array}$ \\
\hline April 1999 & $\begin{array}{l}\text { Resolution and Collection Corporation } \\
\text { (RCC) }\end{array}$ & $\begin{array}{l}\text { A colletion company to purchase and sell collateral- based } \\
\text { NPLs-“in danger of bankruptcy” or blow. }\end{array}$ \\
\hline April 2000 & $\begin{array}{l}\text { Civil Rehabilitation Law (Minji saisei } \\
\mathrm{Ho} \text { ) }\end{array}$ & Facilitates filings and decisions for large number of firms \\
\hline 2000 & Commercial Codes & Procedures for corporate splits introduced. \\
\hline September 2001 & $\begin{array}{l}\text { Voluntary procedures for corporate } \\
\text { debt restructuring based on the London } \\
\text { rules (by INSOL) }\end{array}$ & Guidelines for debt forgiveness agreed. \\
\hline April 2003 & $\begin{array}{l}\text { Corproate Restructuring Law (Kaisha } \\
\text { kosei Ho) }\end{array}$ & $\begin{array}{l}\text { Restructuring provisions eased and some flexibility allowed } \\
\text { in the restructuring measures in line with those of the Civil } \\
\text { Rehabilitation Law. }\end{array}$ \\
\hline April 2003 & $\begin{array}{l}\text { Industrial Revitalization Corporation of } \\
\text { Japan (IRCJ) }\end{array}$ & $\begin{array}{l}\text { Resturucturing of large firms made easier through purchase } \\
\text { of NPLs from all non-main bank creditors. }\end{array}$ \\
\hline
\end{tabular}

Source: Financial Services Agency, Ministry of Finance, OECD.

A framework for voluntary, multi-creditor out-of-court negotiations for corporate restructuring—based on the London rules of the International Federation of Insolvency Professionals (INSOL International)—has been introduced. This introduction is based on the recognition that while legal insolvency procedures secure transparency they lack the speed and 
flexibility needed for efficient corporate debt restructuring. However, the major focus of this voluntary framework has been on setting guidelines for debt forgiveness, rather than on a comprehensive debt restructuring negotiation process. ${ }^{27}$

The government established asset management companies, the Resolution and Collection Corporation (RCC) and the Industrial Revitalization Corporation of Japan (IRCJ). They are designed to promote corporate restructuring and to accelerate the disposal of NPLs by purchasing such loans from banks through 2005, respectively aiming at different types of loans and corporations. The RCC is essentially a collection company that purchases and sells collateralized NPLs, classified as "in danger of bankruptcy” or "bankrupt,” focusing on smaller, non-viable firms. ${ }^{28}$ The IRCJ, in contrast, focuses on higher quality NPLs—classified as "need special attention”- for larger firms. ${ }^{29}$ The objective is to promote restructuring of relatively large, troubled but viable firms by purchasing their loans from secondary banks, leaving the main bank and the IRCJ as the only major creditors.

In recent years, corporate debt/equity ratios have come down and profitability has risen, particularly for large firms due to restructuring measures such as downsizing and cost-cutting. As major banks have also created their own asset management subsidiaries to dispose of NPLs, markets for distressed assets have been developing, thus accelerating the pace of corporate debt restructuring. Nonetheless, smaller firms, particularly in the non-manufacturing sectors, continue to suffer from high leverage, low profitability and excess capital and labor.

\footnotetext{
${ }^{27}$ In the crisis-affected economies of East Asia, formal insitutions to help accelerate the voluntary out-of-court negotiations were established-Corporate Debt Restructuring Advisory Committee in Thailand, Corporte Debbt Restructuring Committee in Malaysia, the Jakarta Initiative Task Force in Indonesia, and Corproate Restructuring Coordination Committee in Korea (see Kawai 2000, Kawai, Lieberman and Mako 2001, Kawai 2001). In Japan, such a formal institution has not been created.

${ }^{28}$ Its function has been strengthened since June 2002, with greater flexibility in deciding the purchase price-i.e., at fair value - and in buying them from healthy institutions until May 2004. As a result, the volume of its transactions has risen significantly recently.

${ }^{29}$ The IRCJ is expected to purchase loans for two years and dispose of them within three years of purchase.
} 


\section{Establishing a Market-based Regulatory and Supervisory Framework}

Regulation and supervision. A final goal of banking sector regulation and supervision is to establish a best-practice regulatory and supervisory framework based on clearly articulated rules and more transparent administration consistent with a competitive, integrated and open banking sector. The authorities have focused on the following:

- A clearly defined system of bank supervision and inspection;

- A system of prudential norms;

- Corporate governance of banks; and

- Enforcement of bank regulation and rules.

To strengthen bank supervision and inspection, the Financial Services Agency (FSA) was newly established, merging the Financial Supervisory Agency and the Financial System Planning Bureau of the Ministry of Finance (MOF) in July 2000. This completed the transfer of supervision, inspection and policy planning functions from the MOF to an independent regulatory agency. ${ }^{30}$ The FSA has been increasing transparency of its operations. Further improvements can be made. For example, the FSA's autonomy could be enhanced by establishing a board with outside members to whom the Commissioner would be accountable, and the FSA could formalize the information exchange arrangements with the Bank of Japan and other regulatory agencies.

A system of prudential norms has been strengthened, including loan classification and loan loss provisioning, capital adequacy requirements, prompt corrective action, and a deposit insurance scheme. First, loan classification and loan loss provisioning have been tightened, based on the October 2002 Program for Financial Revival, particularly through the introduction of the discounted cash flow method for provisioning loans to large "special attention" and "in danger of bankruptcy” borrowers. However, these tighter requirements have been imposed only on major banks, and not on regional banks. As a result, there are currently two standards for loan loss

\footnotetext{
${ }^{30}$ The BOJ still retains the function of bank examination with a view to ensure soundness of its transaction counterparts.
} 
provisioning, i.e., a relatively tight standard adopted by major banks and a less stringent standard applied to regional banks.

Second, on capital adequacy, currently banks without overseas offices_-“domestic banks"-are subject to a BIS capital adequacy ratio of 4 percent compared with 8 percent for “internationally active banks.” In addition, deferred tax credits now represent about a half of the major banks' tier-1 capital, indicating heavy undercapitalization of banks. ${ }^{31}$ In its recent Financial Sector Assessment Program (FSAP) report on Japan, the IMF recommended that all banks should achieve 8 percent capital adequacy ratios and that the inclusion of deferred tax credits in regulatory bank capital should be limited. ${ }^{32}$

Third, prompt corrective action, designed to be a rule-based response to a deterioration of a bank's capital ratio, was introduced in June 1996 and was invoked by the authorities for the first time in May 1999. It forces an undercapitalized bank to take corrective measures to strengthen its capital base and, if it fails to do so, allows the authorities to take further action. Moving away from case-by-case regulation and ad hoc resolution of problem institutions, the procedure helps establish a rule-based system of bank supervision and regulation.

Fourth, a limited deposit insurance scheme was implemented in April 2005. A blanket deposit guarantee was introduced in 1996 in response to a series of financial institution failures that undermined public confidence. It was originally due to be withdrawn in April 2001 but, in late 1999, the government decided to postpone the removal for a year because of concerns about the health of many financial institutions, particularly regional banks and credit cooperatives, and because of the transfer of the supervision and inspection authorities for credit cooperatives from

\footnotetext{
${ }^{31}$ Deferred tax assets (DTAs) are credits against taxes on future income and often included in regulatory capital. A rationale for this practice is that, given the tax authorities' treatment of all loan loss provisions as tax non-deductible unless the loan losses are legally recognized, part of the current loan loss provisions should be considered as capital because future borrower failures would reduce future tax obligations. But TDAs are usable only when the bank makes profits in the future, while not available to meet losses if the bank fails.

${ }^{32}$ The FSA insists that the agency is not in the position to determine the extent of inclusion of deferred tax credits in capital, but that it is the auditors who should decide. However, it is one thing to define capital for accounting purposes, and it is another to define regulatory capital for prudential purposes.
} 
prefecture governments to the national government in April 2000. The guarantee for all but demand deposits was limited to a maximum of 10 million yen from April 1, 2002, but the removal of the blanket guarantee on demand deposits—-which was to have taken place at end-March 2003 — was delayed by a further two years. The limited deposit insurance system is expected to stimulate depositors' incentives to closely monitor the health of banks. As non-interest bearing, settlement accounts remain fully protected, insurance premiums should be collected so that depositors can make a judgment about the costs and benefits of the protected deposits.

Assessments of reform. Table 6 is a summary of OECD assessments of the government's reform program in the financial sector. The reform program is assessed from the perspectives of policy design, stage of implementation, and effectiveness, each with a scale of 0 (no progress) to 3 (satisfactory achievement). The table indicates that the OECD considers progress on capital adequacy to be limited at all levels because of the absence of explicit guidelines for restricting the inclusion of deferred tax assets in banks’ regulatory capital, leaving such judgments to accounting firms. The reform on taxation to promote NPL resolution is rated low for implementation and effectiveness because of the absence of deductions of provisions for doubtful loans and a loss carry-back. The reform of major public financial institutions and postal savings is also rated low at all levels because of the effective postponement of reform —-though there has been some progress in this area recently. Collection of NPLs is rated high because of the progress made by the RCC and the creation of the IRCJ, while rehabilitation of distressed debtors is not judged to have made significant progress. The corporate governance of banks has not been strengthened enough despite the authorities’ pressure on publicly recapitalized banks to improve it. ${ }^{33}$

\footnotetext{
${ }^{33}$ Publicly recapitalized banks are now required to strengthen their corporate governance by following their restructuring plans. The FSA can exercise greater discretion over the corporate governance of banks if they
} 
Table 6. OECD's Assessment of Financial Sector Reform, 2003

\begin{tabular}{|c|c|c|c|c|}
\hline & $\begin{array}{l}\text { Policy } \\
\text { design }\end{array}$ & $\begin{array}{l}\text { Implemen- } \\
\text { tation }\end{array}$ & $\begin{array}{c}\text { Effective } \\
- \\
\text { ness }\end{array}$ & Average \\
\hline $\begin{array}{l}\text { 1. Ensure stricter assessment of loan quality } \\
\text { and adequate provisioning }\end{array}$ & 2 & 2 & 2 & 2.0 \\
\hline 2. Reinforce capital adequacy & 1 & 1 & 1 & 1.0 \\
\hline 3. Strengthen the governance of banks & 2 & 2 & 1 & 1.7 \\
\hline $\begin{array}{l}\text { 4. Change tax system to promote NPL } \\
\text { resolution }\end{array}$ & 2 & 0 & 0 & 0.7 \\
\hline $\begin{array}{l}\text { 5. Support rehabilitation of distressed } \\
\text { debtors }\end{array}$ & 2 & 2 & 1 & 1.7 \\
\hline 6. Encourage the collection of NPLs & 2 & 3 & 3 & 2.7 \\
\hline $\begin{array}{l}\text { 7. Change taxation related to equity } \\
\text { investment }\end{array}$ & 2 & 3 & 2 & 2.3 \\
\hline 8. Consolidate public financial institutions & 1 & 1 & 1 & 1.0 \\
\hline Average & 1.8 & 1.8 & 1.4 & 1.6 \\
\hline
\end{tabular}

Source: OECD, Economic Surveys, Japan, 2003 (Table A.5, p. 209)..

\section{CONCLUDING REMARKS}

Japan has experienced a decade of economic stagnation with a distressed banking sector.

The asset price bubble in the late 1980s and its subsequent collapse in the early 1990s were largely responsible for the emergence of banking sector problems. The absence of a credit culture to rigorously assess and price credit risks of borrowers was also an important factor behind banks'

fall short of the restructuring targets by more than 30 percent, including the resignation of the bank CEO 
overextension of collateral-based but risky loans, all of which was aggravated by weak prudential and supervisory frameworks.

The authorities' earlier "growing out” approach without a comprehensive strategy to address banking sector problems was clearly a mistake in that it allowed a systemic banking crisis to emerge in 1997-98 and a large output loss during 1998-2002. The authorities failed to tackle the problem decisively, comprehensively and early enough because of their:

- Underestimation of the nature and seriousness of the problem;

- Unwarranted expectations of growth which might restore asset values and health in bank balance sheets;

- Continued injection of fiscal resources to support aggregate demand, thereby allowing insolvent firms to survive and delaying the resolution of the problem; and

- Lack of domestic or external constraints and of political leadership that would otherwise have urged them to take more decisive policy action.

Ultimately, the 1997-98 crisis prompted the government to take a more aggressive policy to tackle the problem. Sufficient progress has been made since then on banking sector stabilization and restructuring through: closure or temporary nationalization of non-viable banks; recapitalization of weak banks; tighter loan classification and loan loss provisioning; acceleration of NPL disposal; and corporate debt and operational restructuring. As a result, the worst is over in the Japanese banking system, setting the stage for sustained economic recovery. Though bank capital may still be inadequate, safety nets are fully in place. The credit allocation has been made more rational. Nonetheless, remaining risks are concentrated in regional and smaller banks that are vulnerable to weak local economic conditions, persistent deflation and hikes of the long-term interest rate.

Restoration of a healthy banking system requires a healthy corporate sector and profitable banking businesses_-through better bank management and focus on core competency. Banks are consolidating their businesses and repositioning their core competency in a fierce battle for

and the suspension of bonuses to directors. 
survival. For all of them, the objective is now clearly to maximize the ROE in a departure from the traditional quantitative targets such as expansion of market shares and transactions volume. These elements of strategy are clearly indicative of their resolve for a rebirth in a new environment where they cannot expect traditional protection from the government beyond providing a stable macroeconomic environment and a sound regulatory and supervisory framework. 
Appendix Table

Asset and Borrower Classification Standard for Self-assessment by Banks

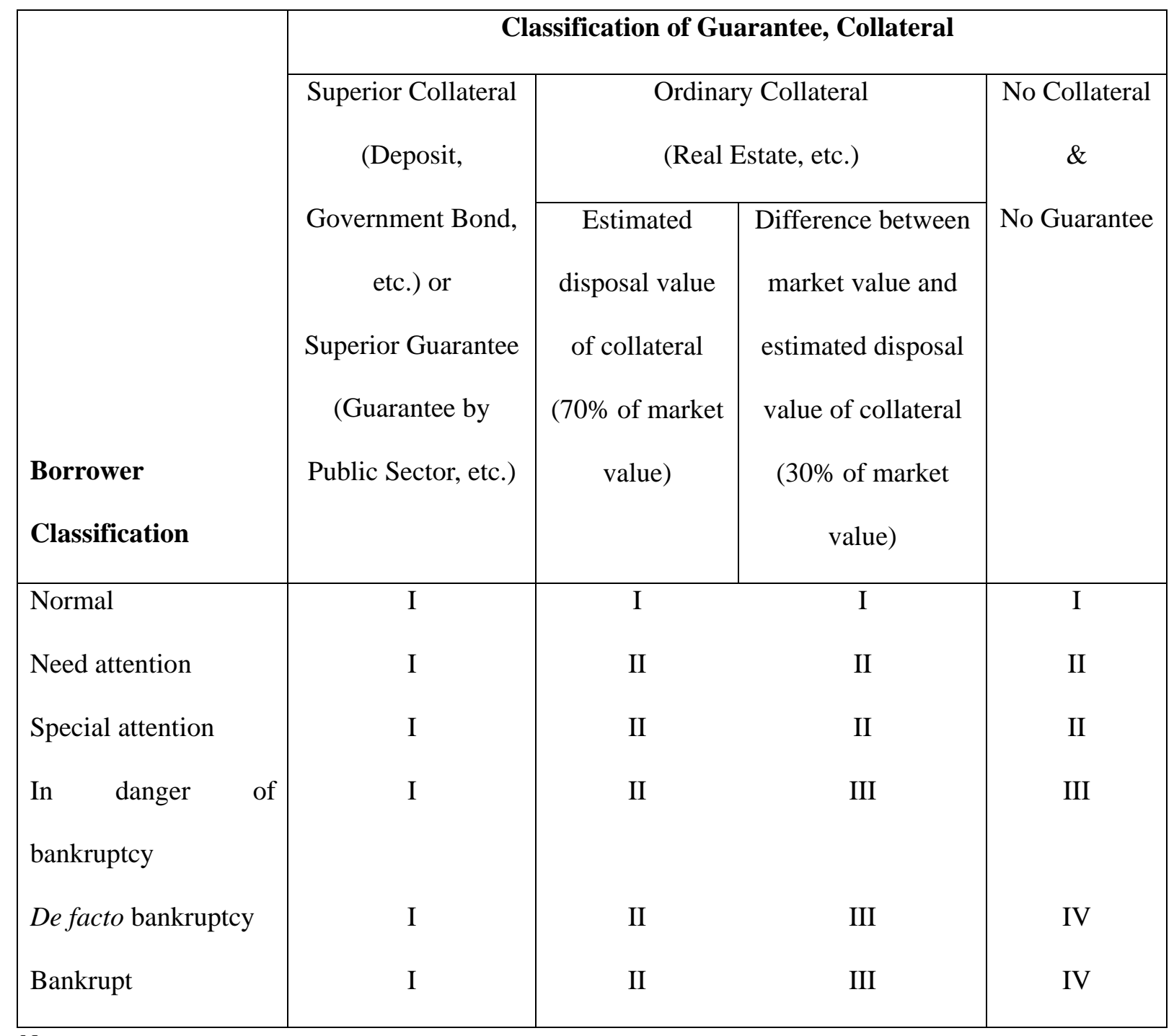

Notes:

(a) Asset classification:

Class I: Assets with no problems in terms of repayment risk or loss value risk.

Class II: Assets deemed to include a higher than normal repayment risk.

Class III: Assets for which there are serious doubts about collection or value.

Class IV: Assets deemed to be uncollectable or without value.

(b) Borrower Classification: 
Normal:

Having strong results and no particular problems with its financial condition.

Need attention: $\quad$ Having problems with lending conditions, fulfillment or its financial conditions, etc.

Special attention: Within the borrowers classified as “need attention”, overdue more than 3 months or having problems with lending conditions (i.e. waivers, reductions or deferrals of interest).

In danger of bankruptcy: Facing business difficulties and failing to make adequate progress on its business improvement plan, so that there is a possibility of falling into bankruptcy in the future.

De facto bankruptcy: $\quad$ Be in serious business difficulties and considered to be impossible to rebuild, though not yet legally and formally bankrupt.

Bankrupt: $\quad$ Legally and formally bankrupt, including bankruptcy, liquidation, reorganization, rehabilitation, composition and suspension of dealings on the bill exchange.

Source: Financial Services Agency. 


\section{REFERENCES}

Bayoumi, Tamim. "The Morning after: Explaining the Slowdown in Japanese Growth in the 1990s.” Journal of International Economics, 53:2 (April 2001), pp. 241-259.

Bayoumi, Tamim and Charles Collyns, ed. Post-Bubble Blues: How Japan Responded to Asset Price Collapse (Washington, DC: International Monetary Fund, 2000).

Brewer, Elijah III, Hesna Genay, William Curt Hunter and George G. Kaufman. "The Value of Banking Relationships during a Financial Crisis: Evidence from Failures of Japanese Banks.” Journal of the Japanese and International Economies, 17:3 (September 2003), pp. 233-262.

Callen, Tim and Martin Muhleisen. "Current Issues Facing the Financial Sector.” Tim Callen and Jonathan D. Ostry, eds., Japan's Lost Decade: Policies for Economic Revival (Washington, DC: International Monetary Fund, 2003), pp. 17-42.

Cargill, T., Michael Hutchison and Takatoshi Ito. The Political Economy of Japanese Monetary Policy (Cambridge, MA: MIT Press, 1997).

Cargill, T., Michael Hutchison and Takatoshi Ito. Financial Policy and Central Banking in Japan (Cambridge, MA: MIT Press, 2000).

Dekle, Robert and Kenneth Kletzer. “The Japanese Banking Crisis and Economic Growth: Theoretical and Empirical Implications of Deposit Guarantees and Weak Financial Regulation.” Journal of the Japanese and International Economies, 17:3 (September 2003), pp. 305-335.

Dell'Aricia, Giovanni. "Banks and Credit in Japan.” Tim Callen and Jonathan D. Ostry, eds., Japan's Lost Decade: Policies for Economic Revival (Washington, DC: International Monetary Fund, 2003), pp. 43-61.

Fukao, Mitsuhiro. "Financial Sector Profitability and Double-Gearing.” Magnus Blomstrom, Jennifer Corbett, Fumio Hayashi, and Anil Kashyap, eds., Structural Impediments to Growth in Japan (Chicago and London: University of Chicago Press, 2003), pp. 9-35.

Hayashi, Fumio and Edward C. Prescott. “The 1990s in Japan: A Lost Decade.” Review of Economic Dynamics, 5:1 (January 2002), pp. 206-235.

Horiuchi, Akiyoshi. “Japan's Banking Crisis and the Issue of Governance.” Peter Drysdale, ed., Reform and Recovery in East Asia: The Role of the State and Economic Enterprise (London and New York: Routledge, 2000), pp. 28-58.

Hoshi, Takeo and Anil Kashyap. "The Japanese Banking Crisis: Where Did It Come from and How Will It End?” Ben Bernanke and Julio Rotemberg, eds., NBER Macroeconomics Annual, 14 (Cambridge, MA: MIT Press, 1999), pp. 129-201.

Hoshi, Takeo and Hugh Patrick. "The Japanese Financial System: An Introductory Overview.” Takeo Hoshi and Hugh Patrick, eds., Crisis and Change in the Japanese Financial System (Norwell, MA: Kluwer Academic, 2000).

International Monetary Fund (IMF). “A Framework for Managing Systemic Banking Crises.” Mimeographed (February 5, 2003), Monetary Exchange Affairs Department, IMF, Washington, 
D.C.

Kanaya, Akihiro and David Woo. "The Japanese Banking Crisis of the 1990s: Sources and Lessons.” IMF Working Paper, WP/00/7 (January 2000), International Monetary Fund, Washington, D.C.

Kawai, Masahiro. "The Resolution of the East Asian Crisis: Financial and Corporate Sector Restructuring.” Journal of Asian Economics, 11 (2000), pp. 133-168.

Kawai, Masahiro. "Bank and Corporate Restructuring in Crisis-Affected East Asia: From Systemic Collapse to Reconstruction.” Pacific Economic Papers, No. 317 (July 2001), pp. 1-45.

Kawai, Masahiro, Ira Lieberman and William P, Mako. "Financial Stabilization and Initial Restructuring of East Asian Corporations: Approaches, Results and Lessons.” Charles Adams, Robert E. Litan and Michael Pomerleano, eds., Managing Financial and Corporate Distress: Lessons from Asia (Washington, DC: Brookings Institutions, 2001), pp. 77-135.

Kawai, Masahiro, Yuzuru Ozeki and Hiroshi Tokumaru. "Banking on East Asia: Expansion and Retrenchment of Japanese Firms.” Vinod K. Aggarwal and Shujiro Urata, eds., Winning in Asia, Japanese Style: Market and Nonmarket Strategies for Success (New York: Palgrave McMillan, 2002), pp. 61-97.

Kawamoto, Takuji. “What Do Purified Solow Residuals Tell Us about Japan's Lost Decade.” Monetary and Economic Studies, 23:1 (February 2005), pp. 113-148.

Krugman, Paul R. “It's Baaack: Japan's Slump and the Return of the Liquidity Trap.” Brookings Papers on Economic Activity, 1998:2, pp. 137-205.

Motonishi, Taizo and Hiroshi Yoshikawa. "Causes of the Long Stagnation of Japan during the 1990s.” Journal of the Japanese and International Economies, 13:3 (September 1999), pp. $181-200$

Nakaso, Hiroshi. "The Financial Crisis in Japan during the 1990s: How the Bank of Japan Responded and the Lessons Learnt.” BIS Papers, No. 6 (October 2001), Bank for International Settlements, Basel.

Smith, David. "Loans to Japanese Borrowers.” Journal of the Japanese and International Economies, 17:3 (September 2003), pp. 283-304. 
Table 1. Loans and Discounts Outstanding by Sector-All Domestically Licensed Banks

(a) Billion Yen

\begin{tabular}{|c|c|c|c|c|c|c|c|c|c|c|}
\hline \multirow[b]{2}{*}{ Year } & \multirow{2}{*}{$\begin{array}{c}\text { Total } \\
\text { Loans \& } \\
\text { Discounts }\end{array}$} & \multirow{2}{*}{$\begin{array}{l}\text { Manufac- } \\
\text { turing } \\
\text { Sector }\end{array}$} & \multicolumn{6}{|c|}{ Non-manufacturing Sector } & \multirow[t]{2}{*}{ Individuals } & \multirow[t]{2}{*}{ All Other } \\
\hline & & & $\begin{array}{c}\text { Total } \\
\text { Non-man. }\end{array}$ & $\begin{array}{l}\text { Wholesale \& } \\
\text { Retail Trade }\end{array}$ & Real Estate & $\begin{array}{l}\text { Finance \& } \\
\text { Insurance }\end{array}$ & Construction & $\begin{array}{c}\text { Other } \\
\text { Non-man. }\end{array}$ & & \\
\hline 1983 & 201,170 & 56,903 & 116,964 & -- & 14,353 & 12,378 & 10,551 & -- & 20,710 & 6,594 \\
\hline 1984 & 223,044 & 59,409 & 133,349 & -- & 16,765 & 16,354 & 11,939 & -- & 21,837 & 8,448 \\
\hline 1985 & 245,505 & 61,909 & 149,740 & -- & 20,605 & 19,414 & 13,328 & -- & 23,468 & 10,387 \\
\hline 1986 & 268,021 & 60,932 & 169,746 & -- & 27,845 & 24,390 & 14,195 & -- & 26,892 & 10,452 \\
\hline 1987 & 293,506 & 57,855 & 191,256 & -- & 32,655 & 31,009 & 14,780 & -- & 33,461 & 10,934 \\
\hline 1988 & 314,318 & 56,405 & 207,147 & -- & 36,742 & 34,894 & 15,598 & -- & 39,673 & 11,094 \\
\hline 1989 & 384,625 & 61,383 & 253,839 & -- & 46,902 & 43,171 & 20,029 & -- & 57,961 & 11,441 \\
\hline 1990 & 408,791 & 61,465 & 270,438 & -- & 48,483 & 45,361 & 20,862 & -- & 65,293 & 11,595 \\
\hline 1991 & 421,083 & 62,824 & 277,176 & -- & 50,625 & 44,371 & 22,495 & -- & 69,306 & 11,777 \\
\hline 1992 & 427,972 & 62,416 & 282,308 & -- & 53,227 & 43,771 & 24,413 & -- & 70,501 & 12,747 \\
\hline 1993 & 511,018 & 79,931 & 336,180 & 77,369 & 59,998 & 54,249 & 30,946 & 113,618 & 81,400 & 13,508 \\
\hline 1994 & 508,850 & 77,861 & 337,110 & 76,413 & 61,036 & 54,974 & 31,853 & 112,834 & 80,791 & 13,088 \\
\hline 1995 & 512,747 & 75,243 & 338,302 & 74,737 & 62,257 & 54,900 & 32,208 & 114,201 & 85,423 & 13,779 \\
\hline 1996 & 512,060 & 73,135 & 335,905 & 73,788 & 63,404 & 51,752 & 31,627 & 115,334 & 88,854 & 14,166 \\
\hline 1997 & 513,748 & 71,140 & 335,670 & 73,147 & 65,032 & 51,627 & 31,857 & 114,008 & 91,657 & 15,280 \\
\hline 1998 & 502,902 & 71,014 & 323,074 & 71,844 & 64,984 & 47,735 & 31,963 & 106,549 & 93,193 & 15,621 \\
\hline 1999 & 493,035 & 73,014 & 311,850 & 70,774 & 62,367 & 44,941 & 30,847 & 102,922 & 94,293 & 13,878 \\
\hline 2000 & 475,282 & 69,493 & 296,385 & 67,206 & 59,603 & 41,612 & 29,230 & 98,734 & 96,048 & 13,357 \\
\hline 2001 & 454,051 & 65,940 & 276,164 & 62,137 & 56,854 & 38,324 & 26,712 & 92,138 & 98,228 & 13,720 \\
\hline 2002 & 432,376 & 61,166 & 256,310 & 56,195 & 53,133 & 37,612 & 23,410 & 85,961 & 100,968 & 13,932 \\
\hline 2003 & 409,875 & 54,117 & 234,804 & 51,102 & 48,201 & 34,985 & 19,794 & 80,723 & 106,681 & 14,273 \\
\hline
\end{tabular}

(b) Percentage Distribution

\begin{tabular}{|c|c|c|c|c|c|c|c|c|c|c|}
\hline \multirow[b]{2}{*}{ Year } & \multirow{2}{*}{$\begin{array}{c}\text { Total } \\
\text { Loans \& } \\
\text { Discounts }\end{array}$} & \multirow{2}{*}{$\begin{array}{c}\text { Manufac- } \\
\text { turing } \\
\text { Sector }\end{array}$} & \multicolumn{6}{|c|}{ Non-manufacturing Sector } & \multirow[t]{2}{*}{ Individuals } & \multirow[t]{2}{*}{ All Other } \\
\hline & & & $\begin{array}{c}\text { Total } \\
\text { Non-man. }\end{array}$ & \begin{tabular}{|l|} 
Wholesale \& \\
Retail Trade
\end{tabular} & Real Estate & $\begin{array}{l}\text { Finance \& } \\
\text { Insurance }\end{array}$ & Construction & $\begin{array}{c}\text { Other } \\
\text { Non-man. }\end{array}$ & & \\
\hline 1983 & 100.0 & 28.3 & 58.1 & -- & 7.1 & 6.2 & 5.2 & -- & 10.3 & 3.3 \\
\hline 1984 & 100.0 & 26.6 & 59.8 & -- & 7.5 & 7.3 & 5.4 & -- & 9.8 & 3.8 \\
\hline 1985 & 100.0 & 25.2 & 61.0 & -- & 8.4 & 7.9 & 5.4 & -- & 9.6 & 4.2 \\
\hline 1986 & 100.0 & 22.7 & 63.3 & -- & 10.4 & 9.1 & 5.3 & -- & 10.0 & 3.9 \\
\hline 1987 & 100.0 & 19.7 & 65.2 & -- & 11.1 & 10.6 & 5.0 & -- & 11.4 & 3.7 \\
\hline 1988 & 100.0 & 17.9 & 65.9 & -- & 11.7 & 11.1 & 5.0 & -- & 12.6 & 3.5 \\
\hline 1989 & 100.0 & 16.0 & 66.0 & -- & 12.2 & 11.2 & 5.2 & -- & 15.1 & 3.0 \\
\hline 1990 & 100.0 & 15.0 & 66.2 & -- & 11.9 & 11.1 & 5.1 & -- & 16.0 & 2.8 \\
\hline 1991 & 100.0 & 14.9 & 65.8 & -- & 12.0 & 10.5 & 5.3 & -- & 16.5 & 2.8 \\
\hline 1992 & 100.0 & 14.6 & 66.0 & -- & 12.4 & 10.2 & 5.7 & -- & 16.5 & 3.0 \\
\hline 1993 & 100.0 & 15.6 & 65.8 & 15.1 & 11.7 & 10.6 & 6.1 & 22.2 & 15.9 & 2.6 \\
\hline 1994 & 100.0 & 15.3 & 66.2 & 15.0 & 12.0 & 10.8 & 6.3 & 22.2 & 15.9 & 2.6 \\
\hline 1995 & 100.0 & 14.7 & 66.0 & 14.6 & 12.1 & 10.7 & 6.3 & 22.3 & 16.7 & 2.7 \\
\hline 1996 & 100.0 & 14.3 & 65.6 & 14.4 & 12.4 & 10.1 & 6.2 & 22.5 & 17.4 & 2.8 \\
\hline 1997 & 100.0 & 13.8 & 65.3 & 14.2 & 12.7 & 10.0 & 6.2 & 22.2 & 17.8 & 3.0 \\
\hline 1998 & 100.0 & 14.1 & 64.2 & 14.3 & 12.9 & 9.5 & 6.4 & 21.2 & 18.5 & 3.1 \\
\hline 1999 & 100.0 & 14.8 & 63.3 & 14.4 & 12.6 & 9.1 & 6.3 & 20.9 & 19.1 & 2.8 \\
\hline 2000 & 100.0 & 14.6 & 62.4 & 14.1 & 12.5 & 8.8 & 6.1 & 20.8 & 20.2 & 2.8 \\
\hline 2001 & 100.0 & 14.5 & 60.8 & 13.7 & 12.5 & 8.4 & 5.9 & 20.3 & 21.6 & 3.0 \\
\hline 2002 & 100.0 & 14.1 & 59.3 & 13.0 & 12.3 & 8.7 & 5.4 & 19.9 & 23.4 & 3.2 \\
\hline 2003 & 100.0 & 13.2 & 57.3 & 12.5 & 11.8 & 8.5 & 4.8 & 19.7 & 26.0 & 3.5 \\
\hline
\end{tabular}

Source: Bank of Japan, Financial and Economic Statistics Monthly. 
Table 3. Outstanding Stock and Disposals of Non-Performing Loans, All Domestically Licensed Banks ${ }^{(a)}$

(End of Fiscal Year)

(Unit: Billion yen)

\begin{tabular}{|c|c|c|c|c|c|c|c|c|c|c|c|c|}
\hline & FY1992 & FY1993 & FY1994 & FY1995 & FY1996 & FY1997 & FY1998 & FY1999 & FY2000 & FY2001 & FY2002 & FY2003 \\
\hline $\begin{array}{l}\text { Non-performing Loans: } \\
\text { Outstanding Stock (b) }\end{array}$ & $\begin{array}{r}-- \\
(12,775) \\
\end{array}$ & $\begin{array}{r}-- \\
(13,576) \\
\end{array}$ & $\begin{array}{r}-- \\
(12,546) \\
\end{array}$ & $\begin{array}{r}28,504 \\
(21,868) \\
\end{array}$ & $\begin{array}{r}21,789 \\
(16,441) \\
\end{array}$ & $\begin{array}{r}29,758 \\
(21,978) \\
\end{array}$ & $\begin{array}{r}29,627 \\
(20,250) \\
\end{array}$ & $\begin{array}{r}30,366 \\
(19,772) \\
\end{array}$ & $\begin{array}{r}32,515 \\
(19,281) \\
\end{array}$ & $\begin{array}{r}42,028 \\
(27,626) \\
\end{array}$ & $\begin{array}{r}34,849 \\
(20,433) \\
\end{array}$ & $\begin{array}{r}26,264 \\
(13,567) \\
\end{array}$ \\
\hline $\begin{array}{l}\text { Loan Loss Provision: } \\
\text { Outstanding Stock }\end{array}$ & $\begin{array}{r}-- \\
(3,698)\end{array}$ & $\begin{array}{r}-- \\
(4,547)\end{array}$ & $\begin{array}{r}-- \\
(5,536)\end{array}$ & $\begin{array}{r}13,293 \\
(10,345)\end{array}$ & $\begin{array}{l}12,334 \\
(9,388)\end{array}$ & $\begin{array}{r}17,815 \\
(13,601)\end{array}$ & $\begin{array}{l}14,797 \\
(9,258)\end{array}$ & $\begin{array}{l}12,230 \\
(7,678)\end{array}$ & $\begin{array}{r}11,555 \\
(6,939)\end{array}$ & $\begin{array}{l}13,353 \\
(8,657)\end{array}$ & $\begin{array}{l}12,585 \\
(7,897)\end{array}$ & $\begin{array}{r}11,430 \\
(6,903)\end{array}$ \\
\hline NPL Disposals & $\begin{array}{r}-- \\
(1,640)\end{array}$ & $\begin{array}{r}-- \\
(3,872)\end{array}$ & $\begin{array}{r}-- \\
(5,232)\end{array}$ & $\begin{array}{r}13,369 \\
(11,067)\end{array}$ & $\begin{array}{r}7,763 \\
(6,210)\end{array}$ & $\begin{array}{r}13,258 \\
(10,819)\end{array}$ & $\begin{array}{r}13,631 \\
(10,440)\end{array}$ & $\begin{array}{r}6,944 \\
(5,398)\end{array}$ & $\begin{array}{r}6,108 \\
(4,290)\end{array}$ & $\begin{array}{r}9,722 \\
(7,721)\end{array}$ & $\begin{array}{r}6,658 \\
(5,105)\end{array}$ & $\begin{array}{r}5,374 \\
(3,461)\end{array}$ \\
\hline New Net LLP & $\begin{array}{l}-- \\
(945)\end{array}$ & $\begin{array}{r}-- \\
(1,146)\end{array}$ & $\begin{array}{r}-- \\
(1,402)\end{array}$ & $\begin{array}{r}7,087 \\
(5,576)\end{array}$ & $\begin{array}{r}3,447 \\
(2,534)\end{array}$ & $\begin{array}{r}8,403 \\
(6,552)\end{array}$ & $\begin{array}{r}8,118 \\
(5,490)\end{array}$ & $\begin{array}{r}2,531 \\
(1,339)\end{array}$ & $\begin{array}{r}2,732 \\
(1,371)\end{array}$ & $\begin{array}{r}5,196 \\
(3,806)\end{array}$ & $\begin{array}{r}3,101 \\
(2,042)\end{array}$ & $\begin{array}{l}1,616 \\
(420)\end{array}$ \\
\hline Direct Write-offs & $\begin{array}{r}-- \\
(424)\end{array}$ & $\begin{array}{r}-- \\
(2,090)\end{array}$ & $\begin{array}{r}-- \\
(2,809)\end{array}$ & $\begin{array}{r}5,980 \\
(5,490)\end{array}$ & $\begin{array}{r}4,316 \\
(3,676)\end{array}$ & $\begin{array}{r}3,993 \\
(3,501)\end{array}$ & $\begin{array}{r}4,709 \\
(4,268)\end{array}$ & $\begin{array}{r}3,865 \\
(3,609)\end{array}$ & $\begin{array}{r}3,072 \\
(2,650)\end{array}$ & $\begin{array}{r}3,974 \\
(3,414)\end{array}$ & $\begin{array}{r}3,520 \\
(3,038)\end{array}$ & $\begin{array}{r}3,734 \\
(3,047)\end{array}$ \\
\hline Other & $\begin{array}{r}-- \\
(271)\end{array}$ & $\begin{array}{r}-- \\
(636)\end{array}$ & $\begin{array}{r}-- \\
(1,022)\end{array}$ & $\begin{array}{r}302 \\
(1)\end{array}$ & $\begin{array}{r}0 \\
(0)\end{array}$ & $\begin{array}{r}863 \\
(766)\end{array}$ & $\begin{array}{r}804 \\
(683)\end{array}$ & $\begin{array}{r}548 \\
(449)\end{array}$ & $\begin{array}{r}304 \\
(269)\end{array}$ & $\begin{array}{r}552 \\
(501)\end{array}$ & $\begin{array}{r}37 \\
(25)\end{array}$ & $\begin{array}{r}25 \\
(-7) \\
\end{array}$ \\
\hline Operating Profits & 4,685 & 4,439 & 4,484 & 6,753 & 6,418 & 5,503 & 3,129 & 4,675 & 4,768 & 4,693 & 4,674 & -- \\
\hline $\begin{array}{l}\text { Total Loans: } \\
\text { Outstanding Stock }\end{array}$ & 474,783 & 477,150 & 477,801 & 482,701 & 482,312 & 477,979 & 472,610 & 463,484 & 456,965 & 440,610 & 423,286 & 411,694 \\
\hline NPL/Total Loan (\%) (c) & -- & -- & -- & 6.6 & 4.9 & 5.5 & 6.1 & 5.4 & 5.3 & 8.4 & 7.2 & 5.2 \\
\hline Capital Adequacy Ratio (\%) & -- & -- & -- & 9.1 & 9.0 & 9.5 & 11.6 & 11.8 & 11.7 & 10.4 & 10.2 & -- \\
\hline
\end{tabular}

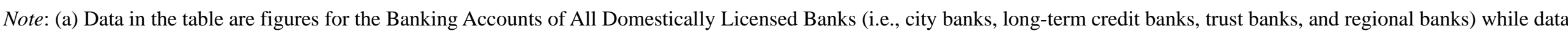
in parentheses are those for city banks, long-term credit banks and trust banks. Data for operating profits and capital adequacy ratios also include foreign trust banks.

(b) Non-performing loans in this table refer to "risk management loans" (losses + loans more than 3 months overdue + restructured loans). Their definitions prior to FY1997 are slightly different: they are losses + overdue loans for FY1992-94 and losses + loans more than 6 months overdue + restructured loans for FY1995-96.

(c) The NPL ratio is for major banks. The capital adequacy ratio is the ratio of capital to risk-weighted assets of major banks.

Source : Financial Services Agency. 


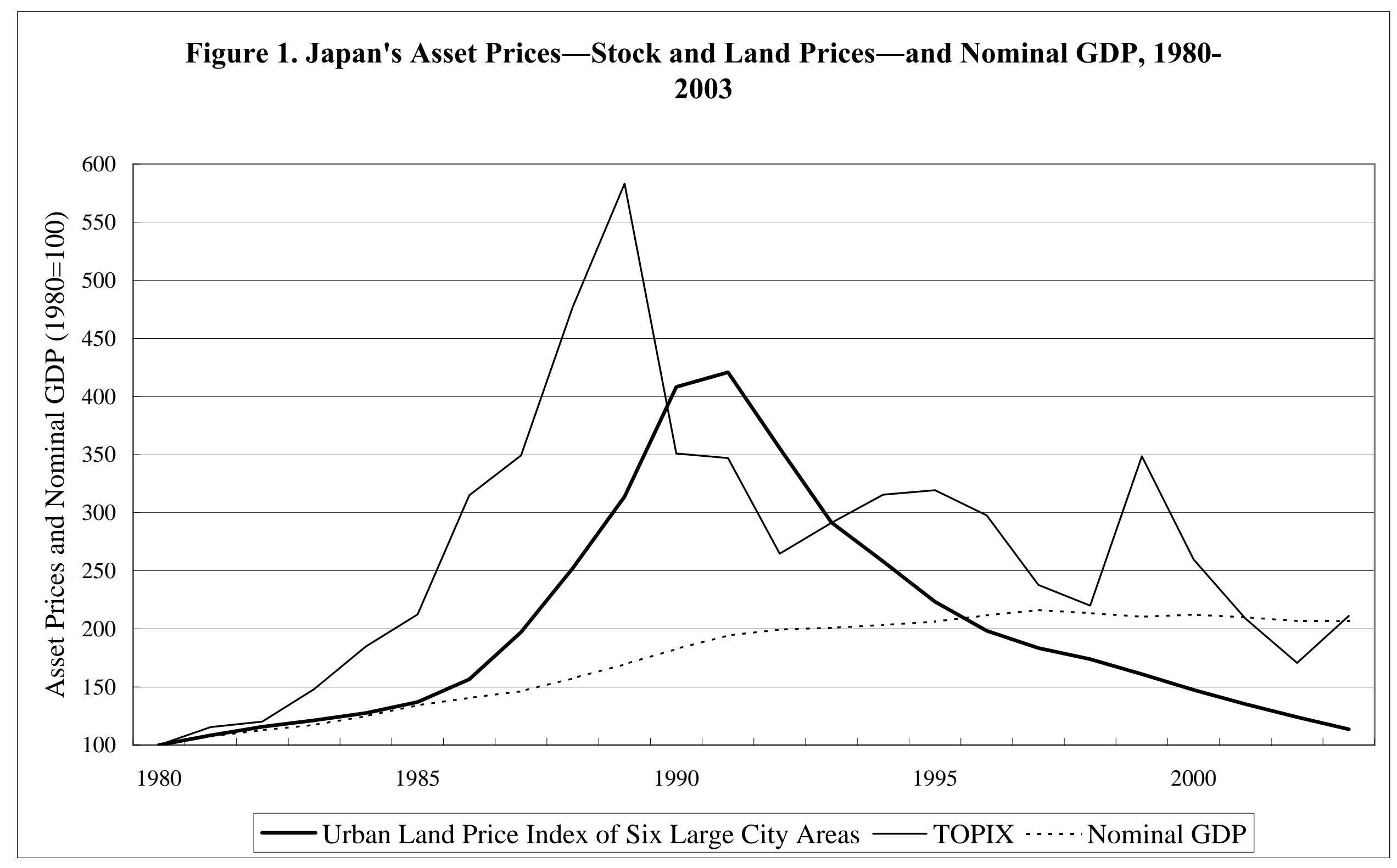




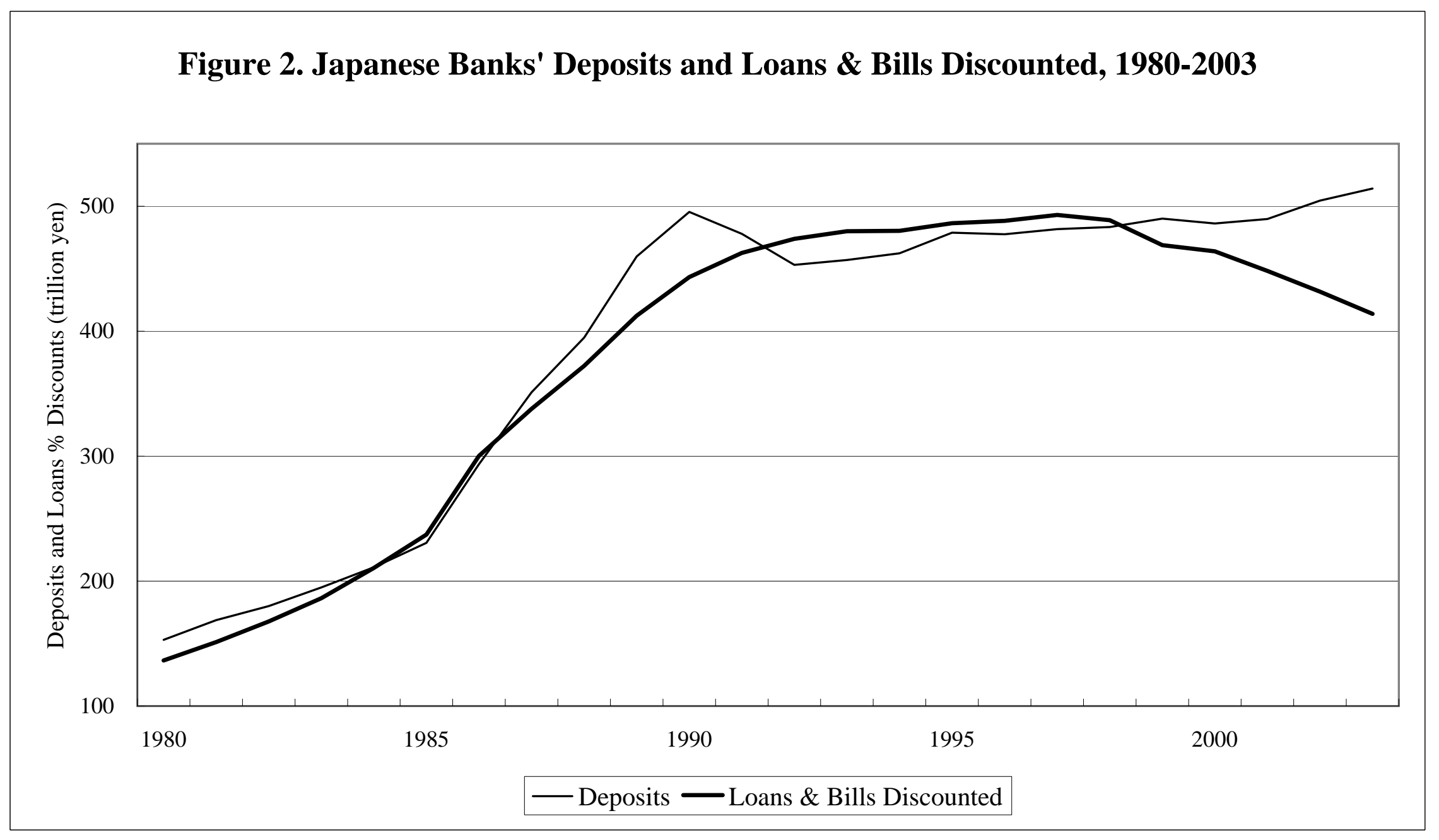

Note: Data are for the banking accounts of all domestically licensed banks (city banks, long-term credit banks, trust banks and regional banks). Source: Bank of Japan, Financial and Economic Statistics Monthly. 